\title{
Effect of Limited Drip Irrigation Regime on Yield and Yield Components of Sesame under Mediterranean Conditions
}

\author{
Panayiota PAPASTYLIANOU*, Dimitrios BILALIS, Ilias TRAVLOS \\ Agricultural University of Athens, Department of Crop Science, Iera Odos 75, 11855, Athens, Greece \\ *)Corresponding author, e-mail: ppapastyl@aua.gr \\ BulletinUASVM Horticulture 74(1) / 2017 \\ Print ISSN 1843-5254, Electronic ISSN 1843-5394 \\ DOI:10.15835/buasvmcn-hort:12639
}

\begin{abstract}
Sesame is one of the most important oilseed crops in the world. Irrigation is of great importance to sesame production due to its positive effect on growth parameters. Although sesame has good drought tolerance compared with many other crops, it is particularly susceptible to drought damage during the seedling, flowering and seed filling stages and this can lead to yield loss. The aim of this study was to determine the response of sesame landraces to different irrigation applications during the 2015 growing season. The experiment was set up as a split plot design with three replicates, four main plots (irrigation treatments, designated as 100\%, 75\% 50\% and 0 of the daily crop evapotranspiration) and two sub-plots (sesame landraces, Limnos and Evros). Different characteristics such as plant height, number of seeds per capsule, and number of capsules per plant, seed yield, 1000 -seed weight and \% capsules without seeds, were recorded. The results indicated that all traits except 1000seed weight were significantly affected by irrigation regimes. Plant height, shattering losses and number of capsules per plant decreased with increasing water shortage. Seed yield and number of seeds per capsule were less affected by irrigation level and showed higher values in the $50 \%$ of the daily crop evapotranspiration treatment. Limnos produced higher seed yield and number of seeds per capsule under all irrigation regimes. Evros showed higher plant height and shattering losses than Limnos. The results of this study suggest that sesame landraces can use water efficiently, are locally adapted and associated with traditional farming systems.
\end{abstract}

Keywords: deficit irrigation, Sesamum indicum, water stress, yield, yield components

\section{Introduction}

Sesame (Sesamum indicum L.) is one of the most important oilseed crops in the world and it is widely used in food, nutraceutical, pharmaceutical and other industries in many countries because of its high oil, antioxidant and protein contents (Uçan et al., 2007). The sesame crop is usually grown under rain-fed conditions, where because of low and irregular precipitation it is regularly subjected to mild to severe water deficit stress. Although sesame has good drought tolerance compared with many other crops, it is particularly susceptible to drought damage during the seedling, flowering and seed filling stages and this can lead to yield loss (Uçan and Killi, 2010). The aim of this study was to determine the response of sesame landraces to different irrigation applications during the 2015 growing season.

\section{Materials and methods}

The research was carried out at the Agricultural University farm located in Athens (southern Greece: latitude $37^{\circ} 58^{\prime} \mathrm{N}$, longitude $23^{\circ} 32^{\prime} \mathrm{E}$, altitude $30 \mathrm{~m}$ above sea level) from July to October 2015 . The soil was clay loam $(29.3 \%$ clay, $33.8 \%$ silt and $36.9 \%$ sand) with pH 7.17, $\mathrm{NO}_{3}-\mathrm{N} 12.4 \mathrm{mg} \mathrm{kg}^{-1}$ soil, available $\mathrm{P} 13.2 \mathrm{mg} \mathrm{kg}^{-1}$ soil, available K $201 \mathrm{mg} \mathrm{kg}^{-1}$ soil and $1.17 \%$ 
Tab. 1. Average values for various characteristics at harvest under different irrigation treatments for Limnos (L) and Evros (E).

\begin{tabular}{|c|c|c|c|c|c|c|}
\hline \multirow[t]{2}{*}{ Irrigation level } & \multicolumn{2}{|c|}{ Height $(\mathrm{cm})$} & \multicolumn{2}{|c|}{$\mathrm{N}$ caps/plant } & \multicolumn{2}{|c|}{ N seeds/caps } \\
\hline & $\mathrm{L}$ & $\mathrm{E}$ & $\mathrm{L}$ & $\mathrm{E}$ & $\mathrm{L}$ & $\mathrm{E}$ \\
\hline 100 & $101 \mathrm{Aa}$ & $102 \mathrm{Aab}$ & $22,1 \mathrm{Aa}$ & $20,0 \mathrm{Aa}$ & $14,3 \mathrm{Aa}$ & $12,3 \mathrm{Aa}$ \\
\hline 75 & $102 \mathrm{Aa}$ & $105 \mathrm{Aa}$ & $14,7 \mathrm{Abc}$ & $14,3 \mathrm{Aab}$ & $19,4 \mathrm{Aa}$ & $15,3 \mathrm{Aab}$ \\
\hline 50 & $85,1 \mathrm{Ab}$ & $89,9 \mathrm{Ab}$ & $15,7 \mathrm{Aab}$ & $16,4 \mathrm{Aa}$ & $29,3 \mathrm{Aa}$ & $26,1 \mathrm{Abc}$ \\
\hline 0 & $61,8 \mathrm{Ac}$ & $60,4 \mathrm{Ac}$ & $8,33 \mathrm{Ac}$ & $7,75 \mathrm{Ab}$ & $21,5 \mathrm{Ab}$ & 19,9 Ac \\
\hline \multirow[t]{2}{*}{ Irrigation level } & \multicolumn{2}{|c|}{ Seed yield (g/plant) } & \multicolumn{2}{|c|}{1000 Seed weight (g) } & \multicolumn{2}{|c|}{ \% caps without seeds } \\
\hline & $\mathrm{L}$ & $\mathrm{E}$ & $\mathrm{L}$ & $\mathrm{E}$ & $\mathrm{L}$ & $E$ \\
\hline 100 & $87,2 \mathrm{Aab}$ & $75,2 \mathrm{Aa}$ & 3,27 & 3,28 & $45,8 \mathrm{Aa}$ & $63,9 \mathrm{Ba}$ \\
\hline 75 & $92,0 \mathrm{Aab}$ & $72,5 \mathrm{Aa}$ & 3,41 & 3,15 & $42,8 \mathrm{Aa}$ & $59,0 \mathrm{Aa}$ \\
\hline 50 & 108,9 Аа & $90,1 \mathrm{Aa}$ & 3,80 & 3,61 & $18,9 \mathrm{Ab}$ & $27,6 \mathrm{Ab}$ \\
\hline 0 & $66,2 \mathrm{Ab}$ & $61,2 \mathrm{Aa}$ & 3,10 & 3,17 & - & - \\
\hline
\end{tabular}

organic matter. The experimental design was split plot with irrigation treatments as the main plot (irrigation treatments, designated as $100 \%, 75 \%$ $50 \%$ and 0 of the daily crop evapotranspiration) and sesame cultivars (sesame landraces, Limnos and Evros) as the sub-plot in a randomized complete block design replicated three times. The plot size of each irrigation treatment was $8 \mathrm{~m} \times 2$ $\mathrm{m}$ and the spacing between each main plot was 3 $\mathrm{m}$ in order to minimize water movement among treatments. The experimental plots were $4 \mathrm{~m} \times$ $2 \mathrm{~m}$ and consisted of 4 rows $0.50 \mathrm{~m}$ apart. Seeds were hand-planted at $3 \mathrm{~cm}$ depth on 2 July with wheat (Triticum turgidum subsp. durum L.) as the preceding crop. The crop was fertilized with $60 \mathrm{~kg}$ $\mathrm{N} \mathrm{ha}^{-1}, 60 \mathrm{~kg} \mathrm{P}_{2} \mathrm{O}_{5}$ ha $^{-1}, 60 \mathrm{~kg} \mathrm{~K}_{2} \mathrm{O} \mathrm{ha}^{-1}$ before planting and in addition $60 \mathrm{~kg} \mathrm{~N} \mathrm{ha}^{-1}$ was applied at the beginning of flowering. The crop was kept free of weeds by hand hoeing when necessary. A surface drip irrigation system was used for irrigation. Water was applied equally to all irrigation treatments from sowing until mid July to sustain early emergence and uniform growth crop stand. The different irrigation treatments were started on 20 July and continued until mid-September. The amount of water applied was about $330 \mathrm{~mm}$, $247 \mathrm{~mm}$ and $165 \mathrm{~mm}$ for the different irrigation treatments. At harvest time (9 October), samples from 10 plants were taken from the middle rows of the plots and different characteristics such as plant height, number of seeds per capsule, number of capsules per plant, seed yield, 1000 -seed weight and \% capsules without seeds, were recorded. The data were subjected to statistical analysis according to the split-plot design (STATGRAPHICS Plus 5.1 logistic package). Differences between treatment means were compared at $\mathrm{P}=5 \%$ with ANOVA in order to find the statistically significant differences.

\section{Results and discussion}

The results indicated that all traits except 1000seed weight were significantly affected by irrigation regimes. Plant height, shattering losses, number of capsules per plant decreased with increasing water shortage (Uçan and Killi, 2010). Seed yield and number of seeds per capsule were less affected by irrigation level and showed higher values in the $50 \%$ of the daily crop evapotranspiration treatment. Limnos produced higher seed yield and number of seeds per capsule under all irrigation regimes. Evros showed higher plant height and shattering losses than Limnos. As reported by Kim et al. (2007) water stress significantly decreased seed yield per plant in sesame but it did not influence its seed weight per plant.

\section{Conclusion}

The results of this study suggest that sesame landraces can use water efficiently, are locally adapted and associated with traditional farming systems. 


\section{REFERENCES}

1. Kim KS, Park SH, Jenks MA (2007). Changes in leaf cuticular waxes of sesame (Sesamum indicum L.) plants exposed to water deficit. J Plant Physiol 164:1134-1143.

2. Uçan K, Killi F, Gençoğlan C, Merdun H (2007). Effect of irrigation frequency and amount on water use efficiency and yield of sesame (Sesamum indicum, L.) under field conditions. Field Crops Res 101:249-258.

3. Uçan K, Killi $F$ (2010). Effects of different irrigation programs on flower and capsule numbers and shedding percentage of sesame. Agric Water Manage 98:227-233. 